\title{
Real Grass and the Light of Other Days
}

\author{
D. E. S. Maxwell \\ Formerly of Queen's University, Belfast
}

Fond memory is one defining aspect of Irish writing, whether, as in Thomas Moore, 'fond' means endearing, or as in Samuel Beckett and Brian Friel, it is tainted by implications of deception and delusion. Moore's 'light of other days' and 'The harp that once through Tara's halls' outline its scope. Memory disinters and reconstructs, in celebration or elegy, fragments of an individual or a collective past. Beckett's characters rummage mostly, it would appear, in dimly apprehended remnants of autobiography. His tramps are trying to find where to be in time and place, but with problematic expectations. Of the single memory which Vladimir and Estragon may perhaps share, Vladimir says 'no use harking back to that.' In Happy Days, Winnie looks for solace in fractured recollections of 'the sweet old style.' Hamm in Endgame refers to a father and mother but the mention of them attracts question marks. Krapp, evoking women known in grossly sexual relations, recurs most often to the tender concord with the girl on the lake, opening her eyes to let him in, more than a merely physical union. Krapp's juggling with the tape confuses temporal sequence. So, capriciously, memory selects, perhaps seeking an objective, recoverable past, perhaps devising fictions willed or involuntary.

The mise-en-scène ostensibly is nowhere in particular. Geography vanishes. We are not to take the stage as representing any real place. Beckett's characters denominate as the world the stage itself. It is a refuge, on it they can tell where they are. 'Nice dimensions, nice proportions,' says Clov of his kitchen. His audience he treats with sardonic derision, reporting their response, seen through his telescope, to what they are watching: 'I see ... a multitude ... in transports . . . of joy. (Pause.) That's what I call a magnifier.' Beyond the stage's fourth wall they are in the zone observed by Clov through the window right, 'zero,' 'grey': 'outside of here it's death!'

The audience is the dangerous world to be kept at bay, the Other. Out there Estragon is beaten and bewildered. On stage he and Vladimir can keep themselves going in a space determined by the objects which both help to distract them and secure a territory - the boots, the hats, the stool, the rope. Clov has similar gear, and Winnie (toothbrush, spectacles, magnifying glass and so on), outside whom are the relics of some unspecified 
calamity. So there they are with their odds and ends in their seemingly placeless habitat. Yet it glances towards a location, however fleeting.

It manifests its shadowy self in Molloy. Ballybaba, so far as Moran's ruminations disclose it, is the townland of Bally, the Molloy country. 'Bally' is perfectly Irish. The 'baba' transports it to some exotic province. The landscape of the Molloy country seems perfectly Irish too, with rather a sinister and unsettling life of its own: 'under the waning sky' the road 'seared the tender pastures... rose and fell at the whim of hills and hollows.' These could be the Wicklow hills ('that some call mountains') through which the characters make their painful ways; or which they have observed, perhaps from Dublin's Nelson's Pillar 'the summit of a monument,' having paid 'their few coppers to climb up the winding stones.' In these parts, as Molloy records them, Flann O'Brien's third policeman would be quite at home, bicycles and all. Yet we recognise it as Irish only, so to speak, out of the corner of the eye, in a glimpse of familiar light and contour, in some idioms of the prose, in a reference to Moore's 'light of other days.' Though not placed on the map, the scenes have a bearing in Ireland.

Ireland has a similar ghostly tenure in the plays. It is in the voices, clearly recognisable in 'Ah stop blatherin"; 'Mister, the bones, you won't be wanting the bones?'; 'He wants to cod me'; 'Then we'd be bollocksed.' Clov sees only desolation outside the window, but Hamm remembers 'Kov (?Cobh) beyond the gulf.' Among Krapp's memories is Miss McGlone 'from Connaught, I fancy.' The 'Groghan' he speaks of is Yeats's Cruachan, the ancient capital of Connaught. It is the scene of a number of Yeats's poems, peopled by the ghosts of legendary heroes and also by crippled beggars and tramps. Beckett's Ireland has strong literary associations; from Yeats it takes the down-and-outs and banishes the heroes. The literary inheritance tends to be thus disintegrated. Beckett was sceptical of a certain preciousness in Yeats's stagecraft, the borrowings from the Japanese Noh, the unfolding and folding of a cloth to frame a play. In Endgame this becomes the disrobing of the dustbins, and, to close, Hamm's covering his face with his handkerchief. In Krapp's Last Tape, Krapp elaborately peels a banana; at the end the tape soundlessly unreels. As Vivian Mercier has shown, ${ }^{1}$ there is sufficient evidence in Happy Days of Winnie's descent from the Anglo-Irish gentry. The 'sweet old style' clings on, in a yellowed newspaper, in Winnie's usually mutilated quotations, 'one's classics.' One that she gets right is 'I call to the eye of the mind,' from Yeats's At the Hawk's Well. In a sardonic touch, Winnie's interlocutor, the decrepit Willie, shares Yeats's name.

Beckett identified and admired in O'Casey's plays the enactment of 'the principle of disintegration.' It is at work in his own, exercised in part by the bits and pieces of Ireland cached in the nooks and crannies of the stage discourse.

For all their very different stages, the social and psychic topography of Beckett's Bally, explored, would admit resemblances to Brian Friel's Ballybeg, surveyed in Philadelphia, Here I Come (1964), Living Quarters (1977), Aristocrats (1979), Faith Healer (1979), Translations (1980) and Dancing at Lughnasa (1990). Ballybeg is the arena for distresses 
central to the lives of Friel's characters. At the heart of them is the apparently irreducible conflict between the search for (or evasion of) an integrated self and the distortions imposed by public voices, social and collective imperatives. The dilemma provokes the shifts and contrivances by which its victims seek to disguise its intransigence: verbal games, rôle-playing, the fictions of a fallible, editing memory. Ballybeg is part of a complex metaphor evoking throughout Friel's work. In the earliest plays one can see embryonic forms of it, dramatic approximations of the image to be made precise.

In the late 1950 s Friel wrote a number of radio plays for the Northern Ireland BBC, his principal occupation at the time being his short stories for the New Yorker. His first stage play was A Doubtful Paradise (1959), produced by the Ulster Group Theatre. Describing it as 'a dreadful play,' Friel has remarked, 'I don't think the Group Company collapsed because of it, but it didn't do them any good.' The play does, imperfectly, announce a continuing theme. Its hero is Willie Logue, acting overseer in the Derry Post Office and a man of large but defective cultural pretensions. They are dedicated in his current phase to French civilisation (classes at the local Technical College). Years of bogus refinement and ill-considered ambitions for his children constitute the illusion which supplants and consoles his dispiriting reality. All of Willie's life, job and family, swims in the focus of his self-deception.

Friel grew up in the original of Willie Logue's Derry. He has said of it that it was 'gentle, sleepy' and 'frustrated and frustrating.' The latter was the condition more forcefully present for the city's Catholic majority. It lived in either apathy or hostility induced by mass unemployment, an administration contemptuous of it, and virtual disenfranchisement. To these adversities - though $A$ Doubtful Paradise does not embody them - one answer might be evasion by the way of the kind of paradise, however doubtful, cultivated by Willie Logue. These images of an urban community economically and culturally repressed, yet obdurately surviving, have impressed themselves profoundly on Friel's imagination: Doire declined, so to speak, to Londonderry. The obduracy of spirit and the Celtic language and mythology implicit in Doire may offer alleviating prospects, though in Friel's work they emerge neither as inviolable sanctuary nor an iconography beyond question. The farce of The Communication Cord (1982) subverts the lament for a lost civilisation in Translations, itself inflected by ambiguity. As a source of metaphor, however, they have more substance and rootedness than the arbitrary affectations of Willie Logue, who ends up deciding to study Esperanto.

Though they are to be variously inferred throughout Friel's work, such broadly political considerations are directly addressed only in The Freedom of the City (1973), to an extent in Aristocrats, in Translations and Making History (1988). More commonly, his protagonists are at odds with private, family life, although clearly in a closely identified social background. They are creatures of circumstance trying to make circumstances their creature. In the moribund Ballybeg fully perceived by Gar O'Donnell in Philadelphia, memories deliver possibly remedial moments which the here-and-now fails to authenticate, though it might be made to by some effort of will or present confirmation of feelings merely remembered. By canvassing such possibilities the brilliant Public/Private dialoguegames give them at least a residual life; equally derisive and despairing, they both express and divert Gar from longings mute in the language of social and domestic exchange. His 
more riotous fantasies - as football star, concert violinist, Romeo of the downtown city - remain however, under control. In The Loves of Cass McGuire, when her brother exiles her to Eden House, Cass gradually bowdlerises her life, past and present, into a romance of home, finally submitting totally to illusion.

Both Gar and Cass are engaged in acts of self-preservation. Disaffected, they look to 'home,' to the scenes and relationships of parish, family, at once enticing and forbidding. In one of their mercurial switches, Public and Private turn from manic invention to commemorate Gar's mother - dead in giving birth to Gar - emblem of a self aware and liberated in a distant Eden:

She was small, Madge says, and wild and young, Madge says, from a place called Bailtefree beyond the mountains; and her eyes were bright, and her hair was loose, and she carried her shoes under her arm until she came to the edge of the village, Madge says....

Such dalliances, as Seamus Deane has suggested, ${ }^{3}$ are at risk of merely sentimental charm: 'Sweet Auburn,' 'Fond memories weave the light of other days.' But Friel's vision has a stringency which questions that spell. Gar's evocation of his mother is fragile, a memory of Madge's memory. So too with his personal recollection of the idyllic fishing trip with his father. There is no corroboration, S.B. cannot remember it. In the present, prospects of communion miscarry - his love for Kate, part lyrical, part farce, is a might-have-been; Ned's fumbling gift of the belt dies in inarticulacy. Gar's intelligence and power of feeling find no objects in reality. They are expressed only in the eloquence of his private speech, in danger of falling in love with itself, so that the fabricated Gars, the cowboy, the dashing lover, may dispossess him of the identity and relationships in whose possibility he never quite loses faith. In Philadelphia this possibility, while not exhausted, is deeply eroded. Cass's 'escape' is a surrender, totally inner, denying her outer circumstances. The theatre audience to which, still brashly confident, she has put her case, has vanished from her consciousness by the end, replaced by her private 'rhapsody.'

The proposed end of these excursions is to make a time and a place habitable; an effort to designate where one is, to transmute its possessiveness, which cannot be exorcised merely by leaving, into a sense of belonging. In the later plays the effort seems increasingly to fail of its purpose. The will to amelioration concedes to the (in both senses) diverting expedients and subterfuges of masquerades. Fox Melarkey in Crystal and Fox (1968) sets out precisely to exhibit the vulnerability of such devices, in his case the illusion sustaining his company of a successful and companionable travelling show. By a systematic programme of betrayal and deceit he achieves the destruction of the show, and with his false confession to Crystal that he had informed on their son, that of his own last self-delusion, the return to an imagined Arcadian innocence of their early years. The Gentle Island (1971) assaults a more general myth, that of Irish pastoral, the purity and continuity of Irish peasant life, represented here by Inishkeen, off the Donegal coast near Ballybeg and about to be deserted by most of its population, in a perfect summer. As Peter, the visitor from Dublin, sees it, 'It's not the weather; it's the...the calm, the stability, the self-possession...the sea, the land, fishing, turf-cutting, milking, a house built by your 
great-grandfather ... You're part of a permanence.' His friend, Shane, one of Friel's ironic jesters, experiences instead a nightmare of physical and psychic mutilation, initiated by events of whose 'truth' there is no objective narration. In the brutality of The Gentle Island is implicit the abandonment of any redeeming Bailtefree.

\section{III}

The Freedom of the City (1973) consolidates and refines the mordant revisionism of The Gentle Island. It does not, in one reading, quite leave the conditions of loss and despair inaccessible to hope of a tenuous kind. Its events allude to Bloody Sunday of 1972 in Derry - where the play is set - when British paratroopers killed thirteen unarmed civilians. The play's victims are Lily, Michael, and Skinner, who take refuge in the city's Guildhall after a Civil Rights march is violently dispersed. Skinner works hard at not taking things, or himself, seriously. Asked by Michael, 'Are you for civil rights at all?,' he replies, 'Course I am. I'm crazy about them. A little drop?' In the course of the play he makes one statement, apart from his stylised last words, owning without flippancy to a belief. 'You march,' he tells Lily, 'because you live with eleven kids and a sick husband in two rooms that aren't fit for animals ... Because you know your children are caught in the same morass.' Lily is part of 'the poor - the majority - stirring in our sleep.' From these harsh indignities of the ghetto Lily distils a comfort of reassuring familiarities and her idealised rendering of domestic life with the Chairman. The familiarities have a certain substance, but essentially the comfort blinks facts as dispiriting as the false magic of Inishkeen. The third victim, Michael, aspires to self-improvement, to the 'dignity' which he thinks the presence of doctors and accountants lent to the early Civil Rights marches. 'Shite,' comments Skinner.

As we see during the trio's sojourn in the Mayor's Parlour, they have each a way of coping with a system whose nature is to absorb the compromise, itself, however derisive, effectively excluding any radical betterment. Having sized things up, Skinner retreats into evasive mockery.

The three of them lie dead on the stage at the start. They have been shot down by British soldiers as they emerge from the Guildhall after a few hours larking about with the civic drink and trappings. Skinner is the animateur of the high jinks, which modulate into his own solitary declaration, and Lily's confession that her son Declan is not just 'shy' but a mongol, a telling off-stage silence. Overshadowing it all is the play's atmosphere of enclosure. The heavy mayoral furniture dominates, the battlemented walls, where the judge conducting the enquiry sits, tower over the stage. The speech of Lily and Skinner is vibrant with the argot of the streets, but its energy is irrelevant to the set of voices encircling them, whose effect is dehumanising. These constitute the duckspeak of officialdom and institutions: the vocabulary of judicial authority; of army commands by loudspeakers; of the balladeer who mythologises the deaths; of the Church commending the 'dignity' admired by Michael, and warning of Godless communism; of the distancing generalisations by the American sociologist, Dodds; of the media clichés. Against these, eloquence and individuality are futile. The Freedom is the first play in which Friel fully 
deploys various registers of speech to dramatise the conflict between the powerful and the dispossessed.

The play's two tableaux may direct our interpretation of it. In the first the three stand, hands aloft, and in words conferred upon them at the moment of death testify each to " a truth.' The final scene reprises the posture and while 'the air is filled with a fifteen-second burst of automatic fire' the three, now mute, remain standing. It invites us to hear their words again, echoing beyond Auden's 'lie of Authority.'

The Freedom of the City, grossly misinterpreted by most English and American critics, is a courageous and disturbing play which did not do well commercially. Nor, by reason of the same qualities, did Volunteers (1975). It takes its place in Friel's vision of a contemporary world where past and present, discontinuous, seek connections that are rarely more than glimpsed. The individual is abandoned to whatever defences he can erect, whistling in the dark. The victims and outcasts (Skinner, Keeney in Volunteers) insulate themselves by flippancy, a deft, ready patter, from the demands of anybody seeking their acquiescence. Their 'acts' deride the consequential language and codes of authority. Volunteers takes up all these concerns. Its setting, a Viking archaeological dig in Dublin, lays bare a past of violence and sacrificial killing. In the present, a group of political prisoners has volunteered, against I.R.A. policy, to work on the site. Unlike Skinner, Keeney is acting out of some principle, a claim to individual autonomy, though he conceals any serious intent under banter. And it is again, in the end, a position of ineffectuality. When the party goes back to prison at the end of their stint their comrades will execute them. The protest is admirable, its representatives are engaging, its motive is an assertion of human self-respect. But although this remains part of our apprehension of the narrative, and to that extent condoles, it is shown to be of no practical account.

Of the plays in this distinct period of Friel's career (1973-79), Living Quarters and Aristocrats return to chronicles of domestic life, here at the crisis of family pretensions in collapse.

The last play in the series, Faith Healer, is, obliquely, a meditation on Friel's own work, a backward look at his encounters with the manipulative arts of dramatic fiction. Whose memory do we trust, Gar's or S.B.'s? In The Gentle Island whom do we believe, Sarah or Manus? The Freedom of the City gives its audience an objective view of events in the Mayor's Parlour. Noone on stage is similarly privileged. And to what end and by what means are these fables concocted? Entertainment? Instruction? Amendment?

The form of Faith Healer is totally unheralded. It consists of four monologues, the first and last spoken by Frank Harvey, the faith healer, who we gradually learn is now dead; the second by Grace, his wife (or mistress), also now dead; and the third by Teddy, his manager. Together they offer a riddling history of their relationships and of Frank's career travelling the villages of Wales and Scotland, their names a recurring litany. At the climax, in a pub yard in Ballybeg, he confronts the savagery of a crowbar, a mallet, a hayfork. Approaching the cripple - 'if you do nothing for him, Mister, they'll kill you' he is submitting to his gift in a mortal test, a sacrifice of self, submission to an incomprehensible Other which can possess or desert him.

The story teases us with details of fact. The narrators have each their own account of the incident at Kinlochbervie: where Grace had her stillborn child; or where Frank heard 
of his mother's death; Teddy's idyllic weather, 'all blue and white and green'; or Grace's 'heavy wet mist.' Each version has its private value. Frank's mission is to cure 'the crippled and the blind and the disfigured and the barren.' The narrators re-shape circumstance to the 'truth' they ordain for it. It is the power to create an illusion, a fiction, without objective being. Frank's power can alter reality, but its operation is fickle, beyond his command. His, he says, is 'a craft without an apprenticeship, a ministry without responsibility, a vocation without a ministry'; and he asks 'Was it all chance? Or skill? Or illusion? Or delusion? Precisely what power did I possess? Could I summon it? When and how? Was I its servant?'

Skill, illusion, control: these are precisely the properties - often recalcitrant implicated in the artistic endeavor, and to comparable ends. The process may dispose events as it chooses, deal as it will with the phenomenal world. Fictional narrative claims equal rights with observed reality, which, by affecting the way we see, it may alter. The fictions of the artist are superior to the illusions designed for personal solace. They alter the contours of the world of fact, not necessarily to our comfort, by displacing our perception of it; and unlike the illusions of everyday, they are brought to dispassionate form. The story of Frank Harvey is a parable of the work and the mysterious powers of the artist, enhancing, deceptive, dangerous. The telling of his story, however, is not reductive exposition of a parable. Faith Healer exists in its triple view of the recounted lives, never detached from the particulars of their travels - the ramshackle van, the seedy halls; nor from the emotions they reveal and dissemble.

Although a sense of mortality, literal or of the imagination, pervades the play, its metaphor properly admits the comic. Teddy's monologue passes with total assurance from Rob Roy the Piping Dog, epitome of the Dedicated Artiste - 'Morning, noon and night he'd sit there blowing the bloody thing and working them bellows with his back leg' - to the loss of Kenlochbervie, Grace's child, 'that little wet thing with the black face and the black body, a tiny little thing, no size at all - a boy it was.' After Frank's triumph at Llanbethian, Teddy recalls, an old farmer whom he has cured pays tribute, 'and whatever way he said Glamorgan it sounded like the whole world.' The remark applies to Faith Healer, whose parable disengages itself from the particular lives.

The first production of Field Day, the theatre company founded by Brian Friel and Stephen Rae in Derry, was Friel's Translations (1980). It is set in a historical past, the 1830s, a crucial period of political and cultural change whose ubiquitous pressures are shown affecting a small, localised group. Imperial Rome and Homer's Troy - Vergil's Tyrian towers in the play's last speech - are points of reference. Though in that perspective all empire is transient, in the action here empire is in the ascendant.

Translations takes place in a hedge-school in Baile Beag/Ballybeg, where the polyglot Hugh teaches Greek and Latin through Irish. A contingent of British sappers is engaged in the first comprehensive mapping of Ireland, a process which involves the anglicising of the Gaelic place-names. Owen, Hugh's younger son, is assisting the project, a job which 
he sees as an academic exercise, not the collusion with a dispossessing colonialism his brother Manus considers it to be. There are rumours of unrest, two of the sappers' horses missing.

Maire, a local girl, falls in love with Lieutenant Yolland, who is enamoured not only of her but of his romantic notion of the place and its language. Their love, thriving on their separate incomprehensions - they have no common language - participates in the wider divisions, which are a dispute about cultural and political sovereignty. With Yolland's disappearance, so too vanishes Maire's dream of 'England,' even more figmental than Yolland's of Ireland and Irish. British army correctness gives way to a programme of escalating reprisals. Sarah, the mute girl who had been learning to speak, reverts to silence.

Baile Beag becoming Ballybeg is an imperfect Eden. The corrupt smell of potato blight portends its other disasters. Its people speak Irish (and are to be taken as doing so on stage). This, with their schooling in Latin and Greek, and ignorance of English, is fertile in metaphor. In the world of Jimmy Jack, Homeric deities, Diarmuid and Grania and his neighbours all co-habit in an exuberant union of fiction and fact. It is a place not wholly certain of its civil being, 'imprisoned,' as Hugh puts it, 'in a linguistic contour that no longer matches the landscape of ... fact.' The fact that was is now being reduced by the deletion of its familiarising names. The anglicised names and their original echo through the play, a requiem for the Gaelic topography - the 'desiderium nostrum - the need of our own. Our pietas.' The loss of the names pre-figures the loss of the language itself:

Yes, it is a rich language, Lieutenant, full of the mythologies of fantasy and hope and self-deception. A syntax opulent with tomorrows. It is our response to mud-cabins and a diet of potatoes, our only method of replying to ... inevitabilities.

It all stacks up enticingly against the utilitarian confidence of an imperialism in its brief heyday. But the play, while doing justice to the object of the pietas and to the urgency of deprivation, is also asking if the eloquence is now speaking for anything beyond itself; and if Hugh is more than the griever for a lost cause. By the end of the play he has shifted his ground, applying to the proposed National School and offering to teach Maire English, yet in his last speech still, it would appear, invoking metaphors of unspecified defiance, a rhetoric that might sanctify the violence hinted in the Donnelly twins. None of this will improve the lot of Ballybeg. Hugh's account of his failure to join the 1798 rebellion has something in it of the farcical heroics of the miles gloriosus, in the end dismissive of action. The status of the very language as cultural register is queried too. Owen explains to Yolland the dubious provenance of 'Tobair Vree.' It enshrines no precision that would be lost by its replacement. Language, like memory, may mislead, not identify. Like a good deal else in Friel's work that stands for the humane, the imaginative, the Gaelic inheritance and Hugh's championship of it harbour their flaws and ineptitudes.

The ordnance survey was part of nineteenth-century England's bureaucratic imposition of its rule over Ireland. It had none of the abrupt conclusiveness of the Irish military defeat at Kinsale in 1601, the locus of Making History (1988). As in Translations, a love story, itself complex and moving, reflects the broader historical entanglements. Here it is the marriage of Hugh O'Neill, Earl of Tyrone, into the New English, the later wave of 
colonists, to Mabel Bagenal, daughter of the Queen's Marshal. When she comes to Dungannon as O'Neill's bride she abandons her own community for a society of which she cannot be wholly a member. Hence the occasional bursts of gibing edginess within the tender, playful relationship.

Mabel's sister, giving a present of seeds, advises, 'Don't plant the fennel near the dill or the two will cross-fertilise...You'll end up with a seed that's neither one thing or the other.' In a cheerlessly symbolic outcome, Mabel and her child die at its birth. This is the domestic exhibition of an antagonism, as O'Neill sees it, between 'two deeply opposed civilisations.' It is a matter not just of possessing territories but of incompatible perceptions of the land. To the Bagenals it is an acreage to be ploughed and planted; to Hugh O'Donnell 'the land is the goddess that every ruler in turn is married to.'

O'Neill declares two aims, 'almost self-cancelling': to keep his compatriots 'in touch with the life they knew before they were overrun...honouring its rituals and ceremonials and beliefs'; and 'to open these people to the strange new ways of Europe.' Archbishop Lombard, O'Neill's self-appointed biographer, has no time for such complicating aims. $O$ 'Neill is to be presented as the unblemished hero leading a united nation and a combative faith against heretical foreign oppression. And it is thus that O'Neill has appeared in Irish political hagiology. The O'Neill of Making History is a much more equivocal, and credible, character. For O'Neill, an oath of allegiance to the English Queen, military collaboration with the Tudors, may be acceptable expedients. His nine youthful years among the English nobility - 'Days without blemish,' he calls them - which Lombard will omit, are a mark of separateness, registered in his normal 'upper class English accent.' In English eyes he is a Judas, in Ireland a Janus, even a Proteus. O'Neill demands of Lombard that he tell 'the truth' - 'Kinsale was a disgrace.' He is 'the schemer, the leader, the liar, the statesman, the lecher, the patriot, the drunk, the soured, bitter émigré.'

But Lombard is 'making' history into a holy crusade led by a Gaelic demigod, an embodiment of nationhood: 'Now is the time for a heroic literature' to inspire an abject people. Another time may allow another history, the 'narrative pattern' it imposes on facts equally determined by politically desirable ends. The play's final scene counterpoints the 'truth' of Lombard's panegyric and whatever the truth may be of O'Neill's fulsome submission to the Queen after Kinsale. Now in Rome hatching ludicrous plots 'Operation Turfmould' - with fellow exiles, he recites it:

(O'Neill's English accent gradually fades until at the end his accent is pure Tyrone.) LOMBARD Son of Feardorch, son of Conn Bacagh, son of Con Mor, son of noble lineage, who was fostered and brought up by the high-born nobles of his tribe -

O’NeILL I do with all true and humble penitency prostrate myself at your feet and absolutely submit myself to your mercy, most sorrowfully imploring your commiseration and appealing only to your clemency -

Making History is about the stratagems of transcribing - selecting? shaping? perverting? - historical facts in order to establish a version of reality, a 'truth' verified by its acceptance, Making History is in a way one of the stories Lombard will not tell. 
Lombard takes his place in Friel's gallery of practitioners of the fabulous. He is perfectly aware of what he is about, conscious of a part in national destiny. In the lesser magnitude of domestic fortunes the characters of Aristocrats struggle to preserve, if only as a largely discredited faith, the high claims of Ballybeg Hall, established with all the jealous care and knowing purpose of a Lombard, now in terminal decline.

Eamon, married from poverty into the O'Donnell Big House, has ruined his diplomatic career by involvement in the Civil Rights movement; Judith, eldest daughter of the house, now nurse to her paralysed father, had taken part in the Battle of the Bogside: 'great betrayal; enormous betrayal,' as her father sees it. But politics is a background murmur in the family deterioration. Eamon sardonically proposes it as a parody saga-From Supreme Court to Sausage Factory. Contemplating the descent from the Lord Chief Justice Great-Grandfather to Casimir the failed solicitor, he concludes that if any children he and Alice might have want to prolong the legal dynasty their only option would be to become criminals. Intrusive voices record the fall. Over the baby-alarm in his bedroom the father's incoherent voice and memory relay travesties of the figure - 'such power, such authority' - he once was; Anna, now a nun in Africa, sends a tape of sentimental memories of long-vanished family evenings. Listening to it precipitates the father's death and hence the postponement of the marriage of the youngest daughter, Claire, to an ageing local widower. The Letterkenny telephone exchange is a barrier to Casimir's calls to his family in Germany. To these disembodied, erratic communications Uncle George, another of the plays' silent bystanders, adds his abrupt, speechless entrances and exits.

Aristocrats is scanning the inheritance of a house, looking at lives demeaned by the autocratic father and the house itself, claustrophobic, introverted. 'Carriages, balls, receptions, wedding, christenings, feasts, deaths, trips to Rome, musical evenings, tennis - That's the mythology' retailed by Eamon's grandmother, a Hall servant. It is supplemented by Casimir's impossible memories of Yeats and other notables (in Eamon's translation, 'Shakespeare, Lenin, Mickey Mouse, Marilyn Monroe') and the prodigious gathering in Vienna of grandfather O'Donnell, Liszt, George Sand, Turgenev, Mendelssohn, Balzac. Casimir's fabrications cast doubt even on the existence of his German wife and children. His croquet game, played without equipment, suspends disbelief. Facts are facts; illusions, beguiling fictions, demur. Closer to reality than Casimir's extravaganzas is the less princely eminence of Eamon's account: 'a family without passion, without loyalty, without commitments; administering the law for anyone who happened to be in power; above all wars and famines and civil strife and political upheaval; ignored by its Protestant counterparts, isolated from the mere Irish, existing only in its own concept of itself...but tough - oh, yes, tough, resilient, tenacious; and with one enormous talent for - no, a greed for survival.' Yet even Eamon is not wholly the sceptic, nor are Casimir's anecdotes wholly groundless. Within these confrontations the characters arrive at more of an armistice than is common in Friel's work, far from exultant, an acknowledgment of 'inevitabilities,' spoken for in Alice's, 'Yes, I'll manage.'

The setting of Dancing at Lughnasa (1990), markedly down from Ballybeg Hall, is a cottage two miles outside the village, home of the Mundy family. Michael, the natural son 
of Chris, one of the five Mundy sisters, narrates the story retrospectively in his adult years; and speaks the part of his seven-year old self, taken to be on stage, but unseen. Also living in the house is the sisters' brother, Father Jack, returned after twenty-five years as a missionary in Uganda. Gerry, Michael's father, pays one of his fleeting visits in each of the two Acts. The year is 1936, there is war in Abyssinia, civil war in Spain, for which Gerry, out of no informed judgement - 'bound to be something right about the cause, isn't there?' - volunteers with the International Brigade.

The scene, apparently placid enough, is alive with tension. Michael remembers from it 'some awareness of a widening breach between what seemed to be and what was, of things ... becoming what they ought not to be.' The seeming is of the sisters making do, of a life orderly enough, with no more than mundane strains and grouses. Agnes and Rose (who is 'simple') knit gloves for a pittance. Maggie is the housekeeper, Kate, a teacher, the family's mainstay both as wage-earner and self-appointed guardian of Catholic pieties. She is kind, bossy, prim, inhibited; and fitfully aware that proclaiming things to be 'beyond my comprehension' is denying a part of her nature. Her acknowledged commitment is to the claims of 'responsibilites and obligations and good order.' She contains the prudish fury provoked by Gerry's arrival, which nevertheless unsettles the domestic mould. He still enchants Chris, and Agnes's tart rejoinders to Kate's discourtesies hint at feelings undeclared - protectiveness? envy? desire? Kate is aware of threat: 'It's all about to collapse.' There are portents. The memory of a long-ago dance disquiets Maggie's equable temper. Rose is being flattered by clandestine assignations with a man from the back-hill families, 'savages' to Kate. Father Jack is ailing, confused, the local priest strangely guarded about him. Both the meagre earnings of Agnes and Rose and Kate's teaching post are at risk.

Though distressful, these anxieties are comprehensible, possibly manageable. Father Jack will mend, the sisters keep going somehow. Underlying these adversities and hopes is Michael's 'what was,' issuing first in the riotous dance of Act I. It is the time of Lughnasa, festival of the pagan god, Lugh. Kate has vetoed attendance at the village harvest dance. Then, as the women go about their chores, the rickety Marconi wireless plays at increasing volume an Irish dance tune. Maggie starts to dance, gradually joined by all but Kate, tightly embraced, the dance 'almost recognizable' but 'caricatured,' 'grotesque.' With 'this parodic reel,' accompanied by yells and singing, 'there is a sense of order being consciously subverted.' At last Kate dances, alone. The action is 'out of character and at the same time ominous of some deep and true emotion.' It must suggest a release from, a defiance of, the normal, the controlled. The music cuts and the women gradually halt, embarrassed now by their sudden abandon. It is impossible to convey the vigour which this dance sequence has on the stage. Wordlessly, it utters the energies which decorum, the rules and codes of society, seek to repress: the spirit of Lugh.

In the back-hills, rituals still celebrate him with, as Rose tells, a bonfire by a spring well and dancing. Kate is scandalised - 'a sorry day to hear talk like that in a Christian home, a Catholic home!' - but later confirms the tale: 'They were doing some devilish thing with a goat.' Father Jack, too, is afflicted not merely with odd mannerisms, forgetfulness. He has been repatriated for having taken up the pagan rites of the leper colony, sacrifices to the goddess Obi and the departed spirits, a call stronger than the 
discipline of the Order. In the family's final disintegration, Agnes and Rose abscond overnight, their fate discovered years later by Michael, derelicts on the Thames Embankment. The remaining sisters struggle on, diminished. The unregenerate Old Adam, which the patina of Christianity can neither wholly repress nor entertain, exacts a destructive retribution.

Such is the bleak outcome. The remembered August has for Michael its more benign disposition. Other dances than the wild reel, ominous of subversion, occupy the stage. Relayed by the erratic Marconi, the dance tunes of the nineteen-thirties accompany the dancing of Gerry and Chris, Gerry and Agnes, 'Dancing in the Dark,' 'Anything Goes.' His final dance with Chris is reported by Michael. It is of the nature of ceremony, his farewell to her, formalising a union between them, 'conscious only of themselves and of their dancing.' These dances are magical, shapely, sensual. They establish a gaiety and grace which transcend Gerry's fecklessness and which are yet part of that, and also of unfulfilled ardours in the sisters' lives. The dancing and its music express without words an orderliness of harmony, spontaneous and fashioned. They summon the final memory, at odds with the facts, an 'atmosphere...nostalgic with the music of the thirties...Dancing as if the very heart of life and all its hopes might be found in those assuaging notes and those hushed rhythms and in those silent and hypnotic movements.'

\section{VI}

The Hampstead Theatre production of Aristocrats in 1988 used real grass for the O'Donnell lawn. The lawn is indeed important and the introductory stage directions give attention to it: 'Most recently it was a lawn that has not been cared for in years. Before that it was a grass tennis court and before that a croquet lawn - but no trace of these activities remains.' It is a kind of archaeology of a house, a past interred under a rundown present, real grass and greener far-off fields. The pasts in Friel's plays encompass the personal and the historical. His contemporary scene is that of (partly) decolonised Ireland and the assertions and surrenders which a seeking into itself imposes. To some degree it has the uncertain status of a detribalised off-shore island marooned between a number of officially venerated pasts and a politically volatile present. Beckett's Ireland, unlike Friel's, is an attenuated figure, but it is a sighting of the same disinheritance. The deprivation of Vladimir and the rest is in part a racial or historical consequence, an image of a colonised post-colonial imagination making do with dispossession.

\section{Notes}

1. V. Mercier, Beckett/Beckett (Oxford: Oxford U. P., 1979), esp. ch. 2.

2. D. Hickey and G. Smith, eds. A Paler Shade of Green, p. 221.

3. S. Deane, ed. Introduction to Selected Plays of Brian Friel (London: Faber, 1984), p. 13. 